\title{
TEST OF A MICROLYSIMETER FOR MEASUREMENT OF SOIL EVAPORATION
}

\section{DANILTON L. FLUMIGNAN ${ }^{1}$, ROGÉRIO T. DE FARIA ${ }^{2}$, BRUNO P. LENA ${ }^{3}$}

\begin{abstract}
Quantifying soil evaporation is required on studies of soil water balance and applications aiming to improve water use efficiency by crops. The performance of a microlysimeter (ML) to measure soil evaporation under irrigation and non-irrigation was evaluated. The MLs were constructed using PVC tubes, with dimensions of $100 \mathrm{~mm}$ inner diameter, $150 \mathrm{~mm}$ depth and 2.5 $\mathrm{mm}$ wall thickness. Four MLs were uniformly distributed on the soil surface of two weighing lysimeters conducted under bare soil, previously installed at Iapar, in Londrina, PR, Brazil. The lysimeters had $1.4 \mathrm{~m}$ width, $1.9 \mathrm{~m}$ length and $1.3 \mathrm{~m}$ depth and were conducted with and without irrigation. Evaporation measurements by MLs $\left(\mathrm{E}_{\mathrm{ML}}\right)$ were compared with measurements by lysimeters $\left(E_{L}\right)$ during four different periods in the year. Differences between $E_{M L}$ and $E_{L}$ were small either for low or high atmospheric demand and also for either irrigated or non-irrigated conditions, which indicates that the ML tested here is suitable for measurement of soil evaporation.
\end{abstract}

KEYWORDS: water management, water balance, lysimeters, soil water.

\section{TESTE DE UM MICROLISÍMETRO PARA A MEDIÇÃO DA EVAPORAÇÃO DO SOLO}

RESUMO: A quantificação da evaporação do solo é requerida em estudos de balanço hídrico de culturas e em aplicações que visam a aumentar a eficiência do uso da água pelos cultivos. O objetivo deste trabalho foi testar um modelo de microlisímetro (ML) para medir a evaporação do solo em condições irrigada e não irrigada. Os MLs foram construídos utilizando tubos de PVC rígido, medindo $100 \mathrm{~mm}$ de diâmetro interno, $150 \mathrm{~mm}$ de profundidade e $2,5 \mathrm{~mm}$ de espessura da parede. Quatro MLs foram assentados sobre a superfície de dois lisímetros de pesagem de alta precisão conduzidos com solo nu, previamente instalados no Iapar, em Londrina-PR. Os lisímetros tinham dimensões de 1,4 $\mathrm{m}$ de largura, $1,9 \mathrm{~m}$ de comprimento e 1,3 $\mathrm{m}$ de profundidade, e estavam sendo conduzidos com e sem irrigação. A evaporação medida nos MLs ( $\left.\mathrm{E}_{\mathrm{ML}}\right)$ foi comparada com a medida nos lisímetros $\left(\mathrm{E}_{\mathrm{L}}\right)$, durante quatro períodos do ano. As diferenças entre $\mathrm{E}_{\mathrm{ML}}$ e $\mathrm{E}_{\mathrm{L}}$ foram mínimas para condições de baixa e elevada demanda atmosférica, e também para condições de solo irrigado ou não irrigado, indicado que o modelo de ML testado neste trabalho é adequado para medir a evaporação do solo.

PALAVRAS-CHAVE: manejo de água, balanço hídrico, lisímetro, água no solo.

\section{INTRODUCTION}

The quantification of soil evaporation (E) is required in several studies such as those related to water balance, irrigation, water use efficiency in agriculture and partition the of components of evapotranspiration.

According to ALLEN (1990), DAAMEN et al. (1995) and ALLEN et al. (1998), the evaporation corresponds to the portion of evapotranspiration that is unusable for crop productivity and its participation as a component of water balance can take on significant values in case of bare soil or when the crop partially covers the ground, especially under conditions of more arid climate.

\footnotetext{
${ }^{1}$ Doutorando em Irrigação e Drenagem, ESALQ/USP, e-mail: daniltonlf@yahoo.com.br.

${ }^{2}$ Prof. Dr. do Departamento de Engenharia Rural, FCAV-UNESP, e-mail: rogeriofaria@ fcav.unesp.br.

${ }^{3}$ Mestrando em Engenharia de Sistemas Agrícolas, ESALQ/USP, e-mail: brunoplena@ usp.br.

Recebido pelo Conselho Editorial em: 14-6-2010

Aprovado pelo Conselho Editorial em: 5-9-2011
} 
According to REICHARDT (1985), SINCLAIR (1990) and ALLEN et al. (1998), the evaporation consists of passing the water of the soil from liquid to gaseous form in the atmosphere, and this process is ruled by physical laws.

The amount of energy available in the environment, usually in the form of solar radiation, substantially influences the evaporation of water. Solar radiation heats the ground surface and the layers of air in contact with it, increasing the temperature and, thus, providing more energy for the evaporative process. The humidity also influences evaporation, as the passage of water from soil to the atmosphere is given by the difference in vapor pressure between the soil surface and the layer of air that is in contact. Finally, the wind favors evaporation due to the fact that the flow of air removes the moist air in contact with the soil surface and leaves the dry air in place, renewing the vapor pressure deficit. All of these climatic variables that influence the evaporative process are known to represent the atmospheric demand (TANNER, 1957; ALLEN et al., 1998).

However, evaporation is not a process that depends only on the condition of the surrounding atmosphere, but also depends on hydro-physical properties of soil. Thus, beside the weather conditions, another condition that influences the evaporation is the water supply of the lower layers in the soil profile to its surface. This supply is regulated by the matric potential and hydraulic conductivity of the soil, been these features conditioned mainly by the soil structure, density and porosity (LEMON, 1956; IDSO et al., 1974).

LEMON (1956), working under laboratory conditions, divided the process of evaporation of water from bare soil in three distinct phases, later proven in the field by IDSO et al. (1974). The first phase is characterized for presenting potential evaporation rate and is dependent only on the conditions prevailing in the atmosphere near the ground. This phase is independent of soil moisture conditions under the assumption that there is no restriction on the upward flow of water in the profile. The first phase ends when is established resistance to the water flow toward the soil surface and the evaporation rate is no longer potential, decreasing with time. In the second phase, the intrinsic soil conditions limit the transport of water in the profile and hence the evaporation rate. Thus, in this phase LEMON (1956) considers that the evaporation rate decreases linearly with the decrease in average moisture of the soil profile and atmospheric conditions are no longer of importance. When the variation of evaporation in response to the decrease of soil moisture becomes very small, losing linearity, the third phase begins. This phase is characterized by a rather slow movement of water toward the surface, due to low hydraulic conductivity of the soil.

For BOND \& WILLIS (1970), the evaporation of water in the soil can be described in two phases, because the authors consider that the third phase rarely happens in practice. Thus, the authors defined the Phase 1, in which the soil is wet and evaporation is led by the demand of the atmosphere, and Phase 2, which is led by the resistance to the flow of water in the soil. According to the authors, this resistance increases with decreasing moisture from the surface layer, causing the evaporation rate to become a decreasing portion of the atmospheric demand.

RITCHIE model (1972) was a major breakthrough in the quantification of soil water evaporation and transpiration separately on cropped surfaces. Their estimate was obtained through the distribution of the energy that drives the two processes as a function of the crop leaf area index, using a simple mathematical description of the evaporative process in two distinct phases.

Usually evaporation is measured in terms of bare soil using lysimeters (WALKER, 1983). For conditions of cultivated soils, models like RITCHIE's (1972) are considered adequate to estimate it, since it cannot separate their measurement of transpiration using lysimeters. As an alternative to the measurement of evaporation in bare or cultivated soil, the use of microlysimeters (ML) is considered adequate (BURT et al., 2005). The MLs are made up of small tubes filled with soil of intact structure, installed at ground level and weighed periodically to measure the difference in mass by evaporation during the period. So far, some studies have succeeded in developing and / or testing the MLs to measure soil evaporation (BOAST \& ROBERTSON, 1982; WALKER, 1983; ALLEN, 
1990; VILLALOBOS \& FERERES, 1990; DAAMEN et al., 1993; EVETT et al., 1995; DALMAGO et al, 2010).

Therefore, the objective of this study was to test a microlysimeter model to measure the soil evaporation in irrigated and non-irrigated conditions, so that it can be used in many applications where it is required.

\section{MATERIAL AND METHODS}

The experiment was conducted at the Agronomic Institute of Paraná (Iapar) in Londrina, PR, Brazil (latitude $23^{\circ} 18^{\prime} \mathrm{S}, 51^{\circ} 09^{\prime} \mathrm{W}$ longitude and altitude of $585 \mathrm{~m}$ ). The soil is classified as Oxisol (EMBRAPA, 1999), showing a layer of 0 to $20 \mathrm{~cm}, 12 \%$ sand, $14 \%$ silt and $74 \%$ clay. The climate is humid subtropical (Cfa) according to Köppen's classification (IAPAR, 1994).

The MLs (Figure 1 and 2) were built with rigid PVC pipes, measuring $100 \mathrm{~mm}$ internal diameter, $150 \mathrm{~mm}$ deep and $2.5 \mathrm{~mm}$ wall thickness, with one of the edges beveled to facilitate penetration into the soil (Figures $1 \mathrm{~B}$ and $2 \mathrm{~A}$ ). It was made also a wrapper to the ML consisting of a tubular-shaped structure of PVC similar to ML, but $110 \mathrm{~mm}$ of internal diameter (Figures 1C, 2A and B).
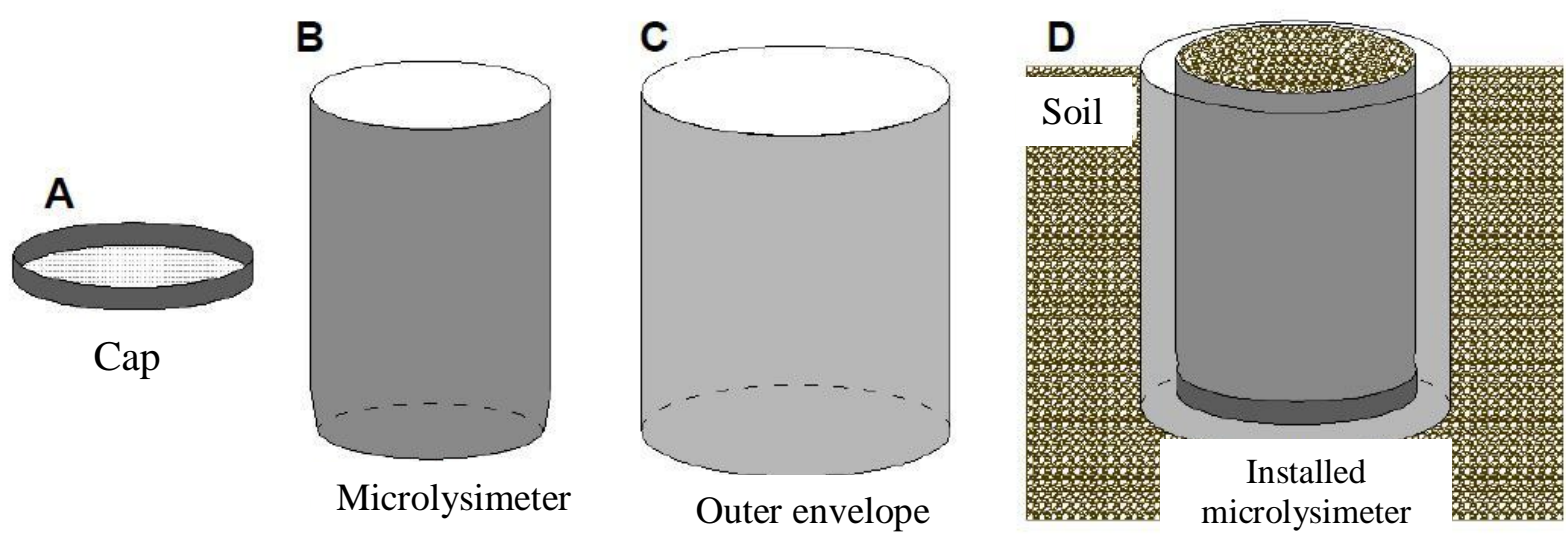

FIGURE 1. Components of a microlysimeter system for measurement of soil evaporation, in which (A) is cap to avoid drainage, (B) is microlysimeter, (C) is outer envelope, and (D) is installed microlysimeter.
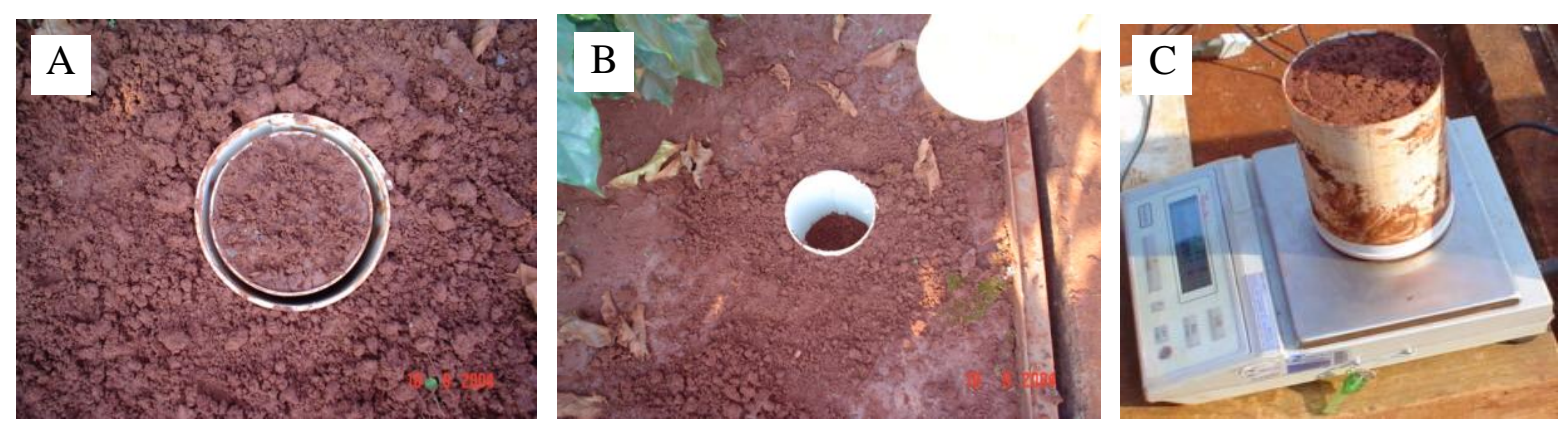

FIGURE 2. Microlysimeter installed with the outer envelope (A), outer envelope in detail (B), and microlysimeter weighing $(\mathrm{C})$.

The ML was filled with soil monolith (Figure 2A), obtained by its penetration into the profile from the tip of the beveled edge, using light strokes with a mallet in a small wooden board positioned at the opposite end of the beveled edge up the soil surface to stay within the ML to approximately $0.5 \mathrm{~cm}$ from the edge. To facilitate the penetration and preserve the soil structure, the walls of the ML were lubricated with a small amount of vegetable oil. 
Once installed, the ML was removed with the aid of a metal extractor with dimensions similar to the wrap, taking care to preserve the structure of the extracted and remaining soil. Besides extracting the ML, the metal extractor was responsible for giving the format required for the insertion of the wrap-site. Then it was cleaned up the external surface and the bottom of the ML was stopped up with plastic cap (Figure1A) and duct tape to hold the soil inside the ML and prevent drainage. This procedure was adopted to ensure that any change in mass of the ML was due only to water evaporation from the soil (EVETT et al., 1995). The installation was completed by placing the envelope on the site where the monolith was extracted, after filling the bottom of the opening with a layer of approximately $0.2 \mathrm{~cm}$ of rice husk to prevent adhesion of the lysimeter soil at the bottom of ML, isolating them in terms of energy exchange (EVETT et al., 1995).

Evaporation of microlysimeter $\left(\mathrm{E}_{\mathrm{ML}}\right)$ was calculated by the following relationship:

$$
E_{M L}=\frac{\Delta M_{M L}}{A_{M L}}+P
$$

In which:

$\mathrm{E}_{\mathrm{ML}}$ - soil evaporation measured with microlysimeter, mm;

$\Delta \mathrm{M}_{\mathrm{ML}}$ - microlysimeter variation of mass, $\mathrm{kg}$;

$\mathrm{A}_{\mathrm{ML}}-$ microlysimeter surface area with a value of $0.00785 \mathrm{~m}^{2}$, and

$\mathrm{P}$ - precipitation, $\mathrm{mm}$.

The precipitation was obtained from the meteorological station of the Institute SIMEPAR located next to the experiment. There were considered null the drainage and runoff due to the seal of the bottom of the ML and the raised edge of the same $(0.5 \mathrm{~cm})$, respectively.

Four MLs were installed evenly distributed over the area of two weighing lysimeters of high precision, one containing bare soil under irrigation and one without. The $\mathrm{E}_{\mathrm{ML}}$ measurements obtained by mass variation of the MLs, by Equation 1, were made daily, at approximately 5pm, using a precision scale and of $1 \mathrm{mg}$ intervals and $2 \mathrm{~kg}$ capacity (Figure 2C). Before weighing the ML were always clean out to remove any aggregated material.

The lysimeter evaporation measurements $\left(E_{L}\right)$ were obtained in the weighing lysimeters every 10 minutes and then accumulated to the same measurement period of the $\mathrm{E}_{\mathrm{ML}}$. Basically, the lysimeters are metal tank with dimensions of $1.4 \mathrm{~m}$ wide, $1.9 \mathrm{~m}$ long and $1.3 \mathrm{~m}$ deep, filled with local soil and placed at ground level (FARIA et al. 2006). It can detect mass change of $0.1 \mathrm{~mm}$ at intervals up to $1 \mathrm{~h}$. The lysimeters are sitting on a metal frame attached to a set of levers to reduce mass by approximately 45 times the total mass (about $6 \mathrm{Mg}$ ). They have a drainage system with water storage tanks made of two PVC pipes placed under the lysimeters, which enable the storage of water percolating through the soil profile. Drainage water is accounted by the weighing system to the opening of the registers. The variation in weight of each lysimeter is measured by a single load cell, which sends electrical signals with a sensitivity of $2+/-10 \mathrm{mV} \mathrm{V}^{-1}$ and works with accuracy of $0.02 \%$ of full scale. The electrical signal from each load cell is captured by a data acquisition system consisting of a multiplexer (AM416 Relay Multiplexer, Campbell Scientific, Logan, USA) and a data storage unit (CR10X, Campbell Scientific, Logan, USA) to later be transferred to a memory module or computer. The conversion of electrical signals to lysimeter mass was performed by regression equations previously calibrated by FARIA et al. (2006).

The $\mathrm{E}_{\mathrm{L}}$ values were determined by accounting of inputs, outputs and storage of water in the lysimeters according to Equation 2:

$$
E_{L}=\frac{\Delta M_{L}}{A_{L}}+P
$$

In which,

$\mathrm{E}_{\mathrm{L}}$ - soil evaporation measured with lysimeter, mm;

$\Delta \mathrm{M}_{\mathrm{L}}$ - lysimeter variation of mass, $\mathrm{kg}$; 
$A_{L}$ - lysimeter surface area with a value of $2.66 \mathrm{~m}^{2}$, and

$\mathrm{P}$ - precipitation, $\mathrm{mm}$.

In Equation 2, it was used the same values of precipitation as mentioned above in the determination of the $\mathrm{E}_{\mathrm{ML}}$ (Equation 1). There were considered null the runoff due to the raised edge of the lysimeters (about $3 \mathrm{~cm}$ ) and the drainage, keeping the reservoirs closed during the evaluation periods.

The irrigation of the irrigated lysimeter was performed before the evaluation period, i.e. between 1 and 10 hours before installation of the ML. To this was applied $10 \mathrm{~mm}$ of water across the surface of the lysimeter using a plastic watering can. Thus, in calculating $\mathrm{E}_{\mathrm{ML}}$ and $\mathrm{E}_{\mathrm{L}}$ the irrigation was considered null.

Besides $\mathrm{E}_{\mathrm{ML}}$ and $\mathrm{E}_{\mathrm{L}}$ it was determined the reference evapotranspiration (ETo) by the hourly ASCE Penman-Monteith method (ASCE-EWRI 2005), using the program REF-ET (ALLEN, 2000) fed with hourly data of the weather station of the SIMEPAR Institute. The hourly values of ETo were accumulated for the same period of analysis of the MLs and the lysimeters.

In order to evaluate the quality of the MLs in the determination of soil evaporation, the averages of four $E_{M L}$ values obtained in each lysimeter were compared with the values of $E_{L}$ for four different periods (June from 07 to 10/05, September from 20 to 23/05, January 31 to February 03/06 and May from 16 to 19/06).

\section{RESULTS AND DISCUSSION}

The evaporation values were lower in non-irrigated treatment, at least until the third or fourth day after irrigation, when the measures became close between treatments due to drying of the topsoil in the irrigated treatment (Figures 3A and B).

A) Non-irrigated
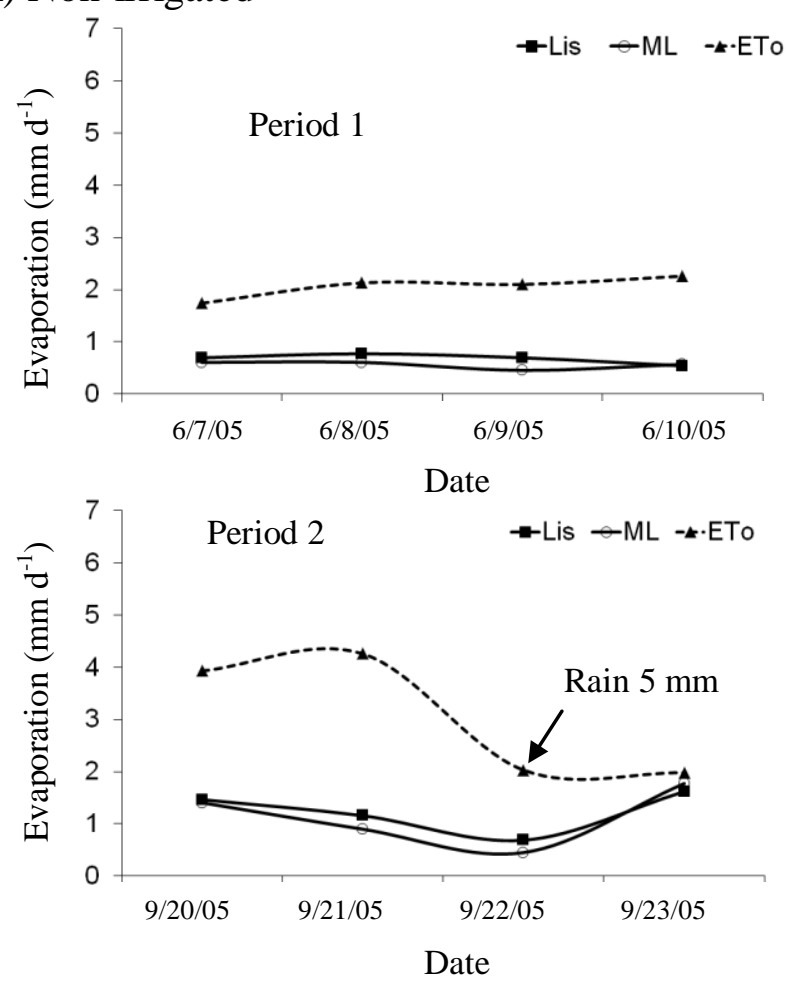

B) Irrigated
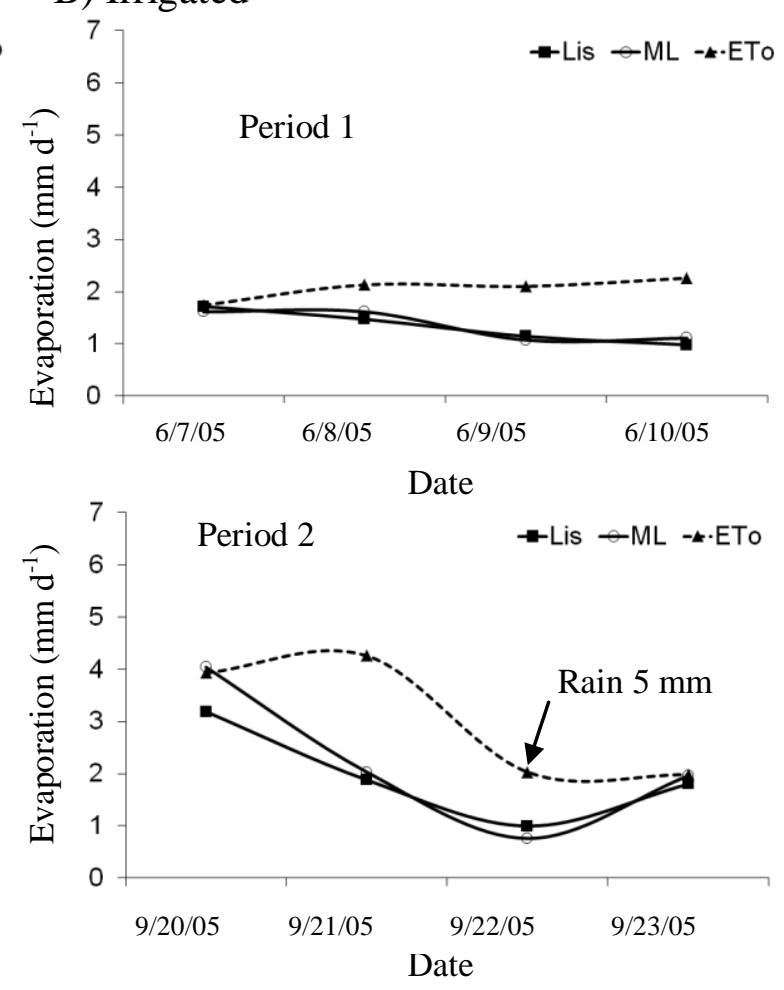

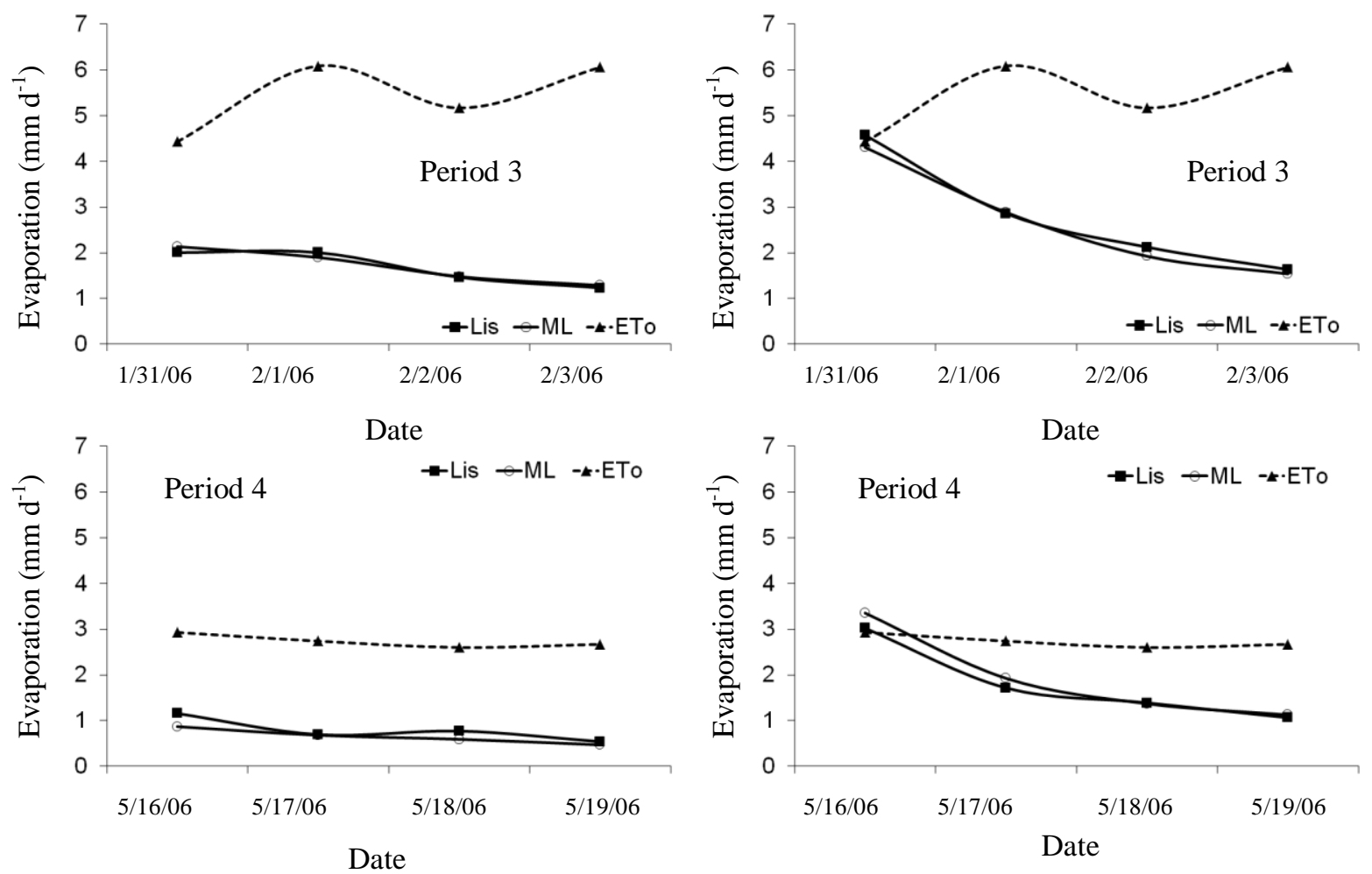

FIGURE 3. Reference evapotranspiration (ETo) and evaporation of bare soil measured by weighing lysimeters (Lis) and microlysimeters (ML) in non-irrigated (A) and irrigated (B) treatments, during four periods, in Londrina, Paraná State, Brazil.

The irrigated treatment had evaporative rates close to the ETo on the day of water application and sudden reduction in subsequent days in all periods analyzed (Figure 3B). Consequently, the evaporative flow demanded by the atmosphere could be supplied by the moist soil for a period of one day only, during which the soil was in Phase 1 of the evaporation process described by LEMON (1956), BOND \& WILLIS (1970) and IDSO et al. (1974). With the decrease of moisture in the topsoil, there was increased the resistance to flow of water in order to attend the atmospheric demand, observing thus Phase 2 on the subsequent days. Importantly, this finding does not suggest that the U parameter of Ritchie's model (RITCHIE, 1972), which indicates the amount of water that must be evaporated to start Phase 2 of the process of evaporation, has the same value of the evaporation determined in first day in the irrigated treatment. This is due to the fact that, conceptually, according to RITCHIE (1972), the value of the U parameter for a particular type of soil should take as a starting point in the soil moisture condition of field capacity. Thus, as irrigation adopted in this experiment was of fixed dephts (equal to $10 \mathrm{~mm}$ ) and thus its application did not ensure that the soil was initially at field capacity condition, it was not possible to determine the U parameter value of Ritchie's model for this soil.

In terms of the observed relationship between evaporation and demand of the atmosphere, during the Period 4 ETo values were found to be on average around $2.74 \mathrm{~mm} \mathrm{~d}^{-1}$ (Figure 3), and that on the first day of evaluation the evaporation in the irrigated treatment was close to the ETo for both measured by the lysimeter $\left(3.02 \mathrm{~mm} \mathrm{~d}^{-1}\right)$ and by ML $\left(3.36 \mathrm{~mm} \mathrm{~d}^{-1}\right)$, indicating the satisfaction of $100 \%$ of the atmospheric demand. In subsequent days, due to drying of the soil surface, evaporation decreased to values close to $40 \%$ of ETo on the last day $\left(1.12 \mathrm{~mm} \mathrm{~d}^{-1}\right.$ for $\mathrm{E}_{\mathrm{ML}}$ and 1.06 $\mathrm{mm} \mathrm{d}^{-1}$ to $E_{\mathrm{L}}$ ). In non-irrigated treatment, as the surface soil was dry due to the lack of precipitation in place for more than 30 days, the evaporation values were low throughout the period 4 , resulting to the last day of the period values of $\mathrm{E}_{\mathrm{ML}}$ and $\mathrm{E}_{\mathrm{L}}$ of 0.47 and $0.54 \mathrm{~mm} \mathrm{~d}^{-1}$, corresponding to 17.5 and $20.1 \%$ of ETo. The comparison between $\mathrm{E}_{\mathrm{ML}}$ and $\mathrm{E}_{\mathrm{L}}$ for that period showed that the largest deviations were only $0.29 \mathrm{~mm} \mathrm{~d}^{-1}$ for non-irrigated treatment and $0.34 \mathrm{~mm} \mathrm{~d}^{-1}$ for the irrigated treatment. In Period 1, which was another period of low demand and lack of precipitation for about 
13 days, the deviations found between $\mathrm{E}_{\mathrm{ML}}$ and $\mathrm{E}_{\mathrm{L}}$ were 0.23 and $0.14 \mathrm{~mm} \mathrm{~d}^{-1}$ for non-irrigated and irrigated treatments, respectively (Table 1).

TABLE 1. Summary of evaporation data obtained by lysimeters (Lis) and microlysimeters (ML) on bare soil under non-irrigated and irrigated treatments in Londrina, Paraná State, Brazil.

\begin{tabular}{|c|c|c|c|c|c|c|c|}
\hline \multirow{3}{*}{ Period } & \multirow{3}{*}{ Date } & \multicolumn{3}{|c|}{ Non-irrigated } & \multicolumn{3}{|c|}{ Irrigated } \\
\hline & & Lis & ML & Deviation & Lis & ML & Deviation \\
\hline & & \multicolumn{6}{|c|}{ (mm) } \\
\hline \multirow{4}{*}{1} & $06 / 07 / 2005$ & 0.69 & $0.60 \pm 0.03$ & 0.09 & 1.72 & $1.61 \pm 0.10$ & 0.11 \\
\hline & 06/08/2005 & 0.77 & $0.60 \pm 0.03$ & 0.17 & 1.47 & $1.61 \pm 0.10$ & -0.14 \\
\hline & 06/09/2005 & 0.69 & $0.46 \pm 0.02$ & 0.23 & 1.14 & $1.07 \pm 0.08$ & 0.07 \\
\hline & $06 / 10 / 2005$ & 0.54 & $0.57 \pm 0.03$ & -0.03 & 0.98 & $1.11 \pm 0.11$ & -0.13 \\
\hline \multirow{4}{*}{2} & $09 / 20 / 2005$ & 1.46 & $1.40 \pm 0.06$ & 0.06 & 3.19 & $4.04 \pm 0.29$ & -0.85 \\
\hline & $09 / 21 / 2005$ & 1.16 & $0.90 \pm 0.02$ & 0.26 & 1.88 & $2.03 \pm 0.10$ & -0.15 \\
\hline & $09 / 22 / 2005$ & 0.69 & $0.45 \pm 0.11$ & 0.24 & 1.00 & $0.76 \pm 0.08$ & 0.24 \\
\hline & $09 / 23 / 2005$ & 1.62 & $1.78 \pm 0.03$ & -0.16 & 1.80 & $1.96 \pm 0.05$ & -0.16 \\
\hline \multirow{4}{*}{3} & $01 / 31 / 2006$ & 2.00 & $2.14 \pm 0.12$ & -0.14 & 4.58 & $4.31 \pm 0.37$ & 0.27 \\
\hline & $02 / 01 / 2006$ & 2.00 & $1.90 \pm 0.11$ & 0.10 & 2.86 & $2.89 \pm 0.20$ & -0.03 \\
\hline & $02 / 02 / 2006$ & 1.46 & $1.48 \pm 0.07$ & -0.02 & 2.12 & $1.92 \pm 0.13$ & 0.20 \\
\hline & $02 / 03 / 2006$ & 1.23 & $1.29 \pm 0.06$ & -0.06 & 1.63 & $1.54 \pm 0.09$ & 0.09 \\
\hline \multirow{4}{*}{4} & $05 / 16 / 2006$ & 1.16 & $0.87 \pm 0.06$ & 0.29 & 3.02 & $3.36 \pm 0.10$ & -0.34 \\
\hline & 05/17/2006 & 0.69 & $0.68 \pm 0.03$ & 0.01 & 1.72 & $1.93 \pm 0.14$ & -0.21 \\
\hline & $05 / 18 / 2006$ & 0.77 & $0.59 \pm 0.04$ & 0.18 & 1.39 & $1.37 \pm 0.08$ & 0.02 \\
\hline & $05 / 19 / 2006$ & 0.54 & $0.47 \pm 0.03$ & 0.07 & 1.06 & $1.13 \pm 0.06$ & -0.07 \\
\hline Average & 16 days & 1.09 & $1.01 \pm 0.05$ & 0.08 & 1.97 & $2.04 \pm 0.13$ & -0.07 \\
\hline
\end{tabular}

Under high atmospheric demand (Period 3), ETo varied between 4.4 and $6.1 \mathrm{~mm} \mathrm{~d}^{-1}$, whereas the maximum differences between the values of $E_{M L}$ and $E_{L}$ were also low, corresponding to 0.14 and $0.27 \mathrm{~mm} \mathrm{~d}^{-1}$ in non-irrigated and irrigated treatment, respectively (Table 1).

In Period 2, characterized by variable air demand, ETo decreased from about $4 \mathrm{~mm} \mathrm{~d}^{-1}$ to about $2 \mathrm{~mm} \mathrm{~d}^{-1}$ after the occurrence of rain on the third day. During this period the maximum difference between $E_{M L}$ and $E_{L}$ was small for the non-irrigated treatment $\left(0.26 \mathrm{~mm} \mathrm{~d}^{-1}\right)$, but relatively higher for the irrigated treatment $\left(0.85 \mathrm{~mm} \mathrm{~d}^{-1}\right.$, obtained on the first day). This larger deviation may be due to the fact that one ML showed a fairly high amount of evaporation of soil water compared to the others, which meant that the average was high and the average error was also one of the highest, indicating the great variability in the ML data for that day (Table 1). The high value of evaporation is apparently related to irrigation, because on that day the water application was performed only one hour prior to the installation of the ML, and that it had rained (45 $\mathrm{mm}$ ) five days prior to installation of the ML, indicating that the surface of the soil was previously wet. Thus, it is possible that the application of water was more concentrated in the region where it was installed the refered ML, together with the fact that was not given enough time to distribute the water in the soil, both laterally and in depth, so that ML had more moisture, and then showed higher evaporation on the first day. In subsequent days, due to the distribution of moisture and considering the evaporative losses from the first day, there was no longer any problem of this type. A similar situation was reported by Allen (1990), in which the values of evaporation in the early days were overestimated when the MLs were installed shortly after the occurrence of precipitation. Thus, it is important to recommend that when installing the ML after an irrigation or rain event, take into account aspects of water depth applied to the soil, long after application and soil water distribuition capacity.

Also in Period 2, the precipitation of $5 \mathrm{~mm}$ occurred during the third day of assessment does not preclude any measures of evaporation obtained in MLs, in disagreement with ALLEN (1990) 
and DAAMEN et al. (1993) who claim that the MLs have faulty data for days with precipitation. This finding may have been differentiated from that found by these authors because the precipitation, as well as small volume, occurred in a distributed manner throughout the day. In other periods evaluated in this study, the data were discarded (data not shown), because the precipitation was concentrated in short periods of evaporation and the values measured in the MLs were not really representative, agreeing to ALLEN (1990) and DAAMEN et al. (1993). The failures in MLs days of precipitation may be associated with several factors, including: inequality of precipitation that reaches the gauge and the ML, differences in measurements between gauges and ML, inhibition of drainage in the MLs, the effect of the impact of drops in the removal of soil particles within the ML, depth and intensity of precipitation. Under conditions of cultivated soil the difference may be even greater, because the canopy intercepts rainwater and distributes unevenly in MLs that are distributed in the soil. Continuing the analysis of the Period 2, it was noted that the next day of the precipitation (fourth day), the measured values of evaporation in both treatments were very close to the ETo, indicating a return to Phase 1 of evaporation described by LEMON (1956), BOND \& WILLIS (1970) and IDSO et al. (1974).

As shown in Table 1, without making distinction between the treatments studied, the deviations found between measurements obtained by lysimeters and MLs were within the range of $\pm 0.3 \mathrm{~mm} \mathrm{~d}^{-1}$ in most cases $(93.75 \%$ of the data $)$ and within the range of $\pm 0.15 \mathrm{~mm} \mathrm{~d}^{-1}$ in more than half $(56.25 \%$ of data).

The $16 E_{M \mathrm{~L}}$ average obtained for treatment with and without irrigation were submitted to regression analysis assuming the values of $E_{L}$ as a reference (Figure 4). It is possible to notice that the data show little scatter about the 1:1 line for both treatments. The point that was farthest from the line was measured for the irrigated treatment on 09/20/2005 (Period 2), as discussed above.

The adjusted equations indicate that the data obtained by MLs and lysimeters were close among them, showing the good agreement between the methods based on high values of $\mathrm{R}^{2}$ found, 0.9263 to non-irrigated treatment and 0.9373 to irrigated. The MLs underestimated the evaporation at $4.4 \%$ for non-irrigated treatment and overestimated at $3.64 \%$ for the irrigated treatment. The underestimation found in the non-irrigated treatment may be related to inhibition of capillary rise that occurs in the ML, limiting the amount of water that rises to the surface of soil to be evaporated, while the overestimation observed in the irrigated treatment may be related to the discrepant measure obtained on 09/20/2005.

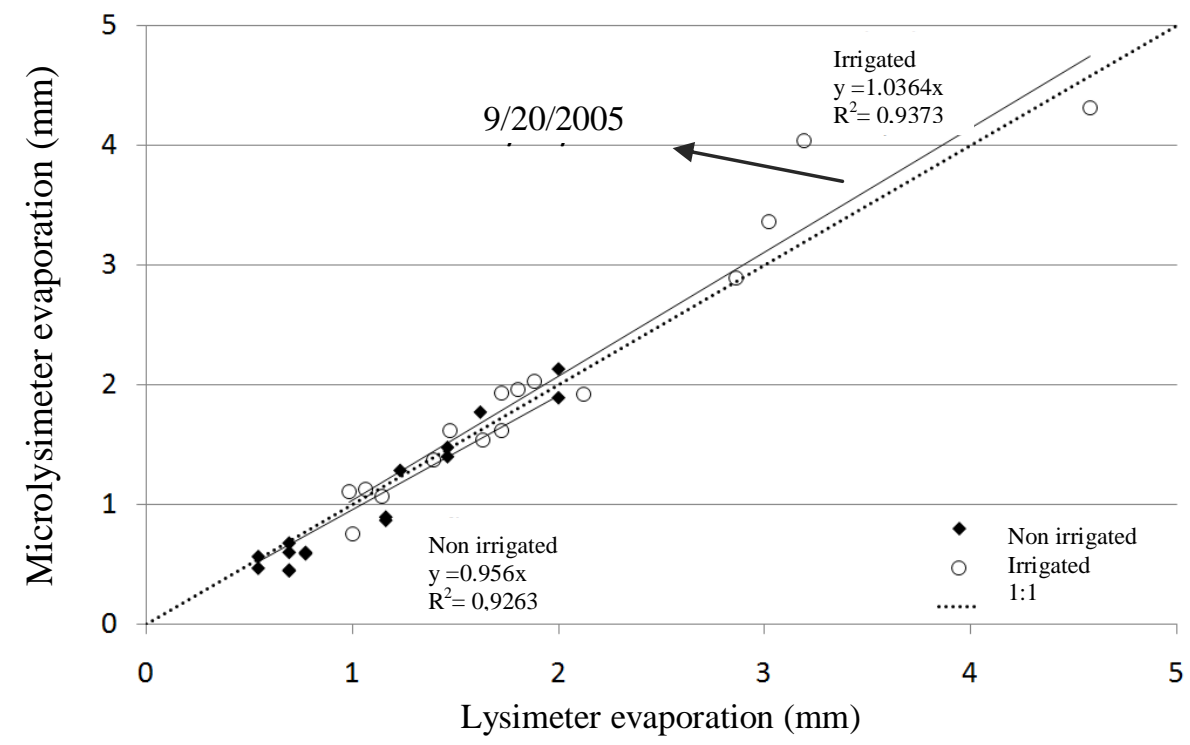

FIGURE 4. Regression of evaporation determined by weighing lysimeters and microlysimeters of bare soil under non-irrigated and irrigated treatments, in Londrina, Paraná State, Brazil. 
In the 16-day trial the accumulated evaporation determined in non-irrigated lysimeter was $17.47 \mathrm{~mm}$ and ML equal to $16.16 \mathrm{~mm}$ (1.31 mm shorter), as shown in Figure 5. Considering the 16 days of measurements, the difference between $\mathrm{E}_{\mathrm{L}}$ and $\mathrm{E}_{\mathrm{ML}}$ can be considered negligible, since it is equivalent to a daily underestimation of only $0.08 \mathrm{~mm}$ for the average daily evaporation of about $1.09 \mathrm{~mm}(<7.5 \%)$. In the irrigated treatment, the value accumulated in the lysimeters was equal to $31.56 \mathrm{~mm}$, while the accumulated value for the MLs was equal to $32.63 \mathrm{~mm}$ (1.07 $\mathrm{mm}$ higher). This overestimation is also considered small, since it is equivalent to the deviation of about $0.067 \mathrm{~mm}$ per day for the average daily evaporation determined on the lysimeters of $1.97 \mathrm{~mm}$, approximately $(<3,5 \%)$.

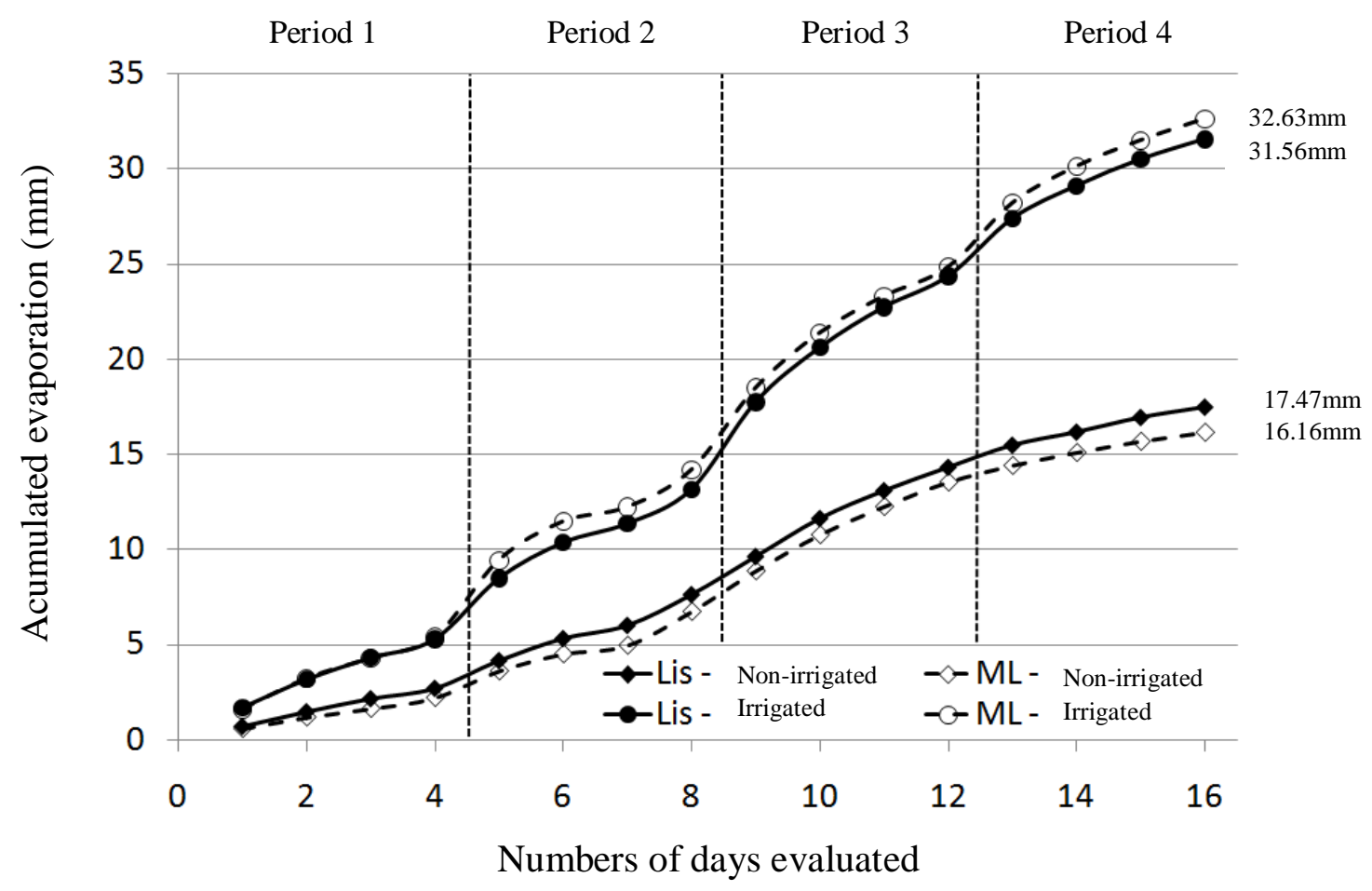

FIGURE 5. Accumulated evaporation of bare soil under non-irrigated and irrigated treatments, determined by weighing lysimeters (Lis) and microlysimeters (ML), during four periods, in Londrina, State of Paraná, Brazil.

In this study, the MLs had reliable measurements for up to four consecutive days without requiring new installation. It is noteworthy that it was not tested if MLs could be used for longer periods even though the data in the literature suggest that the periods obtained by other authors were equal to or smaller than those obtained in this study (DAAMEN et al., 1993).

In general, the life of a ML is directly associated with its moisture from the outer soil, because it assumes that the moisture inside the ML should represent that found in the soil outside (EVETT et al., 1995). Therefore, the lifetime is mainly determined by the physical and hydraulic properties of the soil, by the depth of the ML and the behavior of the atmospheric demand (DAAMEN et al., 1993). First, the physical and hydraulic properties of the soil determine its ability to retain water. This, when combined with depth of the used ML, is the available water capacity in the soil within the ML. The available water capacity is greater, the greater the capacity to retain water in the soil and the greater the depth of the ML. In this condition the lifetime of ML should be higher. Another important factor is the initial moisture content at the time of installation of the ML. It is expected that the lifetime of a ML should be much lower, the lower the initial moisture content, because the amount of available water to be evaporated should be small. Finally, with respect to atmospheric demand in periods of cloudy weather, when the demand is lower, evaporation rates should be low and therefore the lifetime of a given ML will be higher, because the available water to be evaporated in ML is reduced gradually. On the other hand, in a typical clear sky day, when demand 
tends to be higher, evaporation rates should be high, making the water available in the ML to be reduced sharply, which should reduce its useful life.

According to DAAMEN et al. (1993), the lifetime of an ML is also influenced by their sources of intrinsic errors to the method as limiting the drainage and capillary rise caused by the bottom closing, the interruption of the water extraction by the roots by isolating the soil in the case of cultivated soils, the degree of soil disturbance caused during its extraction and heat conduction in the ML.

ALLEN (1990) worked with MLs of similar dimensions to this study and period of lifetime obtained was equal to two days. DAAMEN et al. (1993) working with ML $100 \mathrm{~mm}$ depth obtained lifetime of 3 days. In general, the lifetime of ML obtained by these studies is lower because the authors worked under conditions of semi-arid climates and soils with lower water holding capacity, which caused the moisture inside the ML differs from outside more quickly.

The field activities that were developed in this study demonstrates that the greatest difficulty with respect to the management of MLs is its installation, because due to the clay soil and moist, this procedure requires great care to preserve the soil structure extracted and remaining. Cleaning the outside to be held after the extraction of the ML is also a laborious task, because there is much adhesion of clay in the PVC, being difficult to remove. Studies with the MLs require mainly two people to install, but once installed, it is low laborious, and it requires only the daily presence of a person to accomplish the weighing, which takes a few minutes. In this specific case study where were used eight MLs, two people required approximately one hour to perform its installation.

\section{CONCLUSION}

The microlysimeters model tested in this study is precise and practical to measure soil evaporation in soil irrigated and without irrigation, under low and high atmospheric demand.

\section{ACKNOLEDGEMENTS}

To the Agricultural Technician of Iapar, Jose Carlos da Silva, to the great support in the field and laboratory work.

\section{REFERENCES}

ALLEN, R.G. REF-ET: Reference evapotranspiration calculation software. Version 2.0. Moscow: University of Idaho, 2000. $82 \mathrm{p}$.

ALLEN, R.G.; PEREIRA, L.S.; RAES, D.; SMITH, M. Crop evapotranspiration: Guidelines for computing crop water requirements. Rome: FAO, 1998. 300 p. (FAO Irrigation and Drainage Paper, 56)

ALLEN, S.J. Measurement and estimation of evaporation from soil under sparse barley crops in northern Syria. Agricultural and Forest Meteorology, Amsterdam, v.49, n.4, p.291-309, 1990.

ASCE-EWRI. The ASCE standardized reference evapotranspiration equation: technical committee report to the Environmental and Water Resources Institute of the American Society of Civil Engineers from the Task Committee on Standardization of Reference Evapotranspiration. Reston: ASCE, 2005. $173 \mathrm{p}$.

BOAST, C.W.; ROBERTSON, T.M. A “micro-lysimeter" method for determining evaporation from bare soil: description and laboratory evaluation. Soil Science Society of America Journal, Madison, v.46, n.4, p.689-696, 1982.

BOND, J.J.; WILLIS, W.O. Soil evaporation: first stage drying as influenced by surface residue and evaporation potential. Soil Science Society of America Proceedings, Madison, v.34, n.6, p.924-928, 1970. 
BURT, C.M.; MUTZIGER, A.J.; ALLEN, R.G.; HOWELL, T.A. Evaporation research: Review and interpretation. Journal of Irrigation and Drainage Engineering, New York, v.131, n.1, p.37-58, 2005.

DAAMEN, C.C.; SIMMONDS, L.P.; SIVAKUMAR, M.V.K. The impact of sparse millet crops on evaporation from soil in semi-arid Niger. Agricultural Water Management, Amsterdam, v.27, n.3-4, p.225-242, 1995.

DAAMEN, C.C.; SIMMONDS, L.P.; WALLACE, J.S.; LARYEA, K.B.; SIVAKUMAR, M.V.K. Use of microlysimeters to measure evaporation from sandy soils. Agricultural and Forest Meteorology, Amsterdam, v.65, n.3-4, p.159-173, 1993.

DALMAGO, G.A.; BERGAMASCHI, H.; KRÜGER, C.A.M.B.; BERGONCI, J.I.; COMIRAN, F.; HECKLER, B.M.M. Evaporação da água na superfície do solo em sistemas de plantio direto e preparo convencional. Pesquisa Agropecuária Brasileira, Brasília, v.45, n.8, p.780-790, 2010.

EMBRAPA. EMPRESA BRASILEIRA DE PESQUISA AGROPECUÁRIA. Sistema brasileiro de classificação de solos. Rio de Janeiro: EMBRAPA-CNPS, 1999. 412p.

EVETT, S.R.; WARRICK, A.W.; MATTHIAS, A.D. Wall material and capping effects on microlysimeter temperatures and evaporation. Soil Science Society of America Journal, Madison, v.59, n.2, p.329-336, 1995.

FARIA, R.T.; CAMPECHE, F.S.M.; CHIBANA, E.Y. Construção e calibração de lisímetros de alta precisão. Revista Brasileira de Engenharia Agrícola e Ambiental, Campina Grande, v.10, n.1, p.237-242, 2006.

IAPAR. INSTITUTO AGRONÔMICO DO PARANÁ. Cartas climáticas do estado do Paraná. Londrina, 1994. 49p. (Documento, 18).

IDSO, S.B.; REGINATO, R.J.; JACKSON, R.D.; KIMBALL, B.A.; NAKAYAMA, F.S. The three stages of drying of a field soil. Soil Science Society of America Journal, Madison, v.38, n.5, p.831837, 1974.

LEMON, E.R. The potentialities for decreasing soil moisture evaporation loss. Soil Science Society of America Proceedings, Madison, v.20, n.1, p.120-125, 1956.

REICHARDT, K. Processos de transferência no sistema solo-planta-atmosfera. 4. ed. Campinas: Fundação Cargill, 1985. 445p.

RITCHIE, J.T. Model for predicting evaporation from a row crop with incomplete cover. Water Resources Research, Washington, v.8, n.5, p.1204-1213, 1972.

SINCLAIR, T.R. Theoretical considerations in the description of evaporation and transpiration. In: STEWART, B.A.; NIELSEN, D.R. Irrigation of agricultural crops. Madison: American Society of Agronomy, 1990. p.343-361. (Agronomy, 30)

TANNER, C.B. Factors affecting evaporation from plants and soils. Journal of Soil and Water Conservation, Ankeny, v.12, p.221-227, 1957.

VILLALOBOS, F.J.; FERERES, E. Evaporation measurements beneath corn, cotton and sunflower canopies. Agronomy Journal, Madison, v.82, n.6, p.1153-1159, 1990.

WALKER, G.K. Measurement of evaporation from soil beneath crop canopies. Canadian Journal of Soil Science, Ottawa, v.63, n.1, p.137-141, 1983. 